\title{
Review of Teachers Professional Development Research Studies in South East Asia
}

\author{
Setiawan, W.A ${ }^{1}$, Kuswandono, $\mathbf{P}^{2}$ \\ ${ }^{1,2}$ Sanata Dharma University, Indonesia \\ Corresponding email: widiartoadhi@gmail.com
}

\begin{abstract}
This article discusses and reviews English teacher professional development (TPD) research studies carried out in South East Asia between 2010 and 2018. There is a need to review previous English TPD because new teaching methods are required to develop $21^{\text {st }}$-century students' competencies due to the aim of changing the focus of English learning in school from grammar to conversational English and the use of computers in the classroom. This study aims to find the focus and types of English TPD trends in South East Asia to improve our understanding of what contributes to the effectiveness of the TPD programmes, which, in turn, may facilitate successful implementation of innovations in English language education. The researchers used the ERIC, Scopus and Google Scholar search engines to find English TPD research papers in South East Asia. The reviewed studies were conducted in Singapore, Indonesia, Malaysia, Thailand and Vietnam. The researchers performed the analysis by reviewing the studies and coding them for themes and notions using the frame based on the checklist proposed by Hunzicker (2011), namely supportive, job-embedded, instructional focus and ongoing components for TPD analysis. These reviewed studies appeared to be focused on observation research and action research.
\end{abstract}

Keywords: collaborative TPD; effective TPD; instructional focus TPD; jobembedded TPD; supportive TPD; Teacher Professional Development (TPD)

DOI: https://dx.doi.org/10.20961/ijpte.v4i1.33686 


\section{INTRODUCTION}

This paper discusses and reviews English teacher professional development (TPD) research studies carried out in South East Asia between 2010 and 2018. The need to review previous studies on English TPD is urgent because new teaching methods are required to develop $21^{\text {st }}$-century student competencies, such as effective communication, collaboration and self-direction (Darling-Hammond, Hyler \& Gardner, 2017). Meanwhile, in the last eight years, many published articles have focused on the research and development programme design for teachers, particularly regarding the extent to which teachers and students experience changes in their learning. However, areas beyond research and development studies, for example, types of TPD that engender substantial impacts on teachers, are still underrepresented. Henceforth, this research attempts to review the types of English TPD trends in South East Asia, particularly in Indonesia, Malaysia, Thailand, Singapore and Vietnam. The impacts of the TPD programmes on teachers are also discussed.

English language education faces various problems, including changes to the English curriculum and English language leaching (ELT) practices. In addition, teachers usually work in isolation and have little support from their superiors. Most of, if not all, the current TPD programmes in English language education are designed to reform efforts for the successful innovation of English language education. Hollins and Guzman (2005) conclude that the most effective English TPD is to give teachers experience in class, which improves their capacity to understand, relate to and work with English language learners (ELLs). The growing consensus of what teachers need to learn must be learned from practice rather than in preparation for practice; this stresses the importance of field experiences in TPD. Many theories concerning TPD are available worldwide; some of them are presented below.

TPD, with the 'application of theory' model, prepares teacher candidates to learn theory at university. They then practice or apply their knowledge in school (Korthagen \& Kessels, 1999). The knowledge that students receive in campus courses (first space) often disconnect with their practices in their school placements (second space). Meanwhile, Zeichner (2010) proposes the concept of a 'third space' to remedy this disconnection. The third space is a hybrid space in teacher education, in which knowledge from university, practitioners and communities come together in service of teacher training. This third space rejects binaries such as universities and practitioners, or theories and practice, and merges knowledge that is often seen as a competing discourse. Amos and Kukar (2016) more convincingly argue that the direct incorporation of theories/strategies into practice provide an opportunity for participants to manipulate their strategies and make judgements on their own. This means that participants learn by themselves and for themselves.

In light of the above arguments, this review will provide an analysis of recent research on TPD in English language education in South East Asia. Its goal is to study the focus and the types of English TPD trends in South East Asia to 
improve our understanding of what contributes to the effectiveness of the programmes. In turn, this may facilitate the successful implementation of innovations in English language education. First, the discussion begins with an analytical frame used to analyse the studies. This frame is built on current insights into what makes TPD effective. Second, the literature search is described, showing the search method, selection criteria and method of analysis. Third, the results are presented, starting with some general results, followed by an analysis of the studies, using the frame based on the checklist of Hunzicker (2011). The review ends with a discussion of some critical reflections and directions for future research.

\section{The standards of achievement in education}

Day and Sachs (2004) state that what students must achieve as an outcome of learning, and what standards to apply, are explicitly the everyday business of the state. Governments have intervened more actively to improve schooling systems because of the need to raise standards of achievement in education. The continuing demand from society for improvements in the quality of education has cause the need for effective professional development for teachers as well as preservice teachers. However, the desire to improve the quality of education is a good aim in its own right and it will always continue, no matter what has already been achieved.

\section{Types of effective TPD}

Due to large amounts of daily work, teachers prefer open-ended learning activities to address problems and create solutions that relate to their lives. Open-ended learning activities allow them to control the pace and direction of their professional development. Hunzicker (2011) provides a checklist for effective TPD. It consists of supportive, job-embedded, instructional focus and ongoing components. As an example, for the supportive component it asks, 'Does it combine the needs of individuals with school/district goals?' For the jobembedded component, it asks 'Does it connect to teachers' daily responsibilities?' The checklist serves as a guide for designing TPD, which is more useful than a 'one shot', 'sit and get' presentation-style workshop. An effective TPD is anything that engages teachers in learning activities that are supportive, jobembedded, instructionally focused, collaborative and ongoing (Hunzicker, 2011). Teachers are more likely to be interested in these characteristics of TPD, which make improvements in their learning and teaching practice.

TPD is considered as supportive if it recognises the burden, obligation and interest of the teachers and their school. Reinforced teachers are more inclined to try new things, even if it means they take professional risks.

A job-embedded TPD is concerned with teachers' daily responsibilities. This TPD occurred during the school day, which allowed teachers to engage in various activities such as mentoring and coaching. Teachers tend to be active in jobembedded TPD due its nature, which relates to their daily duties.

An instructionally focused TPD emphasises on student learning outcomes. Such TPD requires teaching assignment differentiation, professional stages and 
teachers' concern about innovation. It also gives meaningful feedback for teachers about whether or not students are motivated to learn.

Collaborative TPD engages teachers in both active and interactive learning. TPD is active when teachers engage physically, cognitively and emotionally through activities such as problem solving, discussion and simulations. It becomes interactive when teachers share problems and viewpoints and work together towards solutions. Ongoing TPD is a combination of contact hours, duration and coherence. The more time teachers engage in TPD, the more likely their teaching practice is to improve. When teachers have multiple opportunities to interact with information and ideas over several months, they can understand the 'whole picture', which makes them more motivated and committed to the ongoing learning process.

There are many research papers concerned with TPD worldwide; this research will review recent journals on English TPD in South East Asia. We focus our review on the ways in which the research studies were carried out. The research question that guides our review is: 'What types of English TPD are carried out in South East Asia?'

\section{RESEARCH METHOD}

The researchers employed document analysis and coded the contents into themes and subthemes (Bowen, 2009). Due to time constraints, only research studies from South East Asia were included. To determine the way that English TPD studies were carried out in this region, the researchers utilised ERIC, Scopus, and Google Scholar search engines by inputting keywords, such as 'English teacher, teacher professional development' with the name of a country to find studies related to TPD. The connective 'and' was used to maximise the discovery of potential studies. Research papers containing TPD were downloaded and were utilised for this review. Only journals published between 2010 and mid-2018 were selected. Of those, 34 studies were downloaded; they were conducted in five countries: Singapore, Indonesia, Malaysia, Thailand and Vietnam. The downloaded papers were selected using criteria that included only English TPD in this study; non-English studies were excluded. From the 34 studies downloaded, only 22 studies conformed to the selected criteria. The researchers then performed analysis by reviewing these studies and coding them for key notions using the frame based on the Hunzicker's (2011) checklist The two themes were used to analyse studies on English TPD, namely: the focus of TPD and types of TPD. Each theme had several sub themes; it should be noted that one study could contain more than one TPD sub themes. The analysis results of the English TPD studies in South East Asia are presented below.

\section{RESULT AND DISCUSSION}

Two themes were used to group the found studies: the focus and the types of TPD. The first theme (the focus of TPD) contained three sub themes as shown in Table 1. The sub themes were observation research, action research and lesson study. 
From the 22 studies, most (14) were observation research studies, followed by seven studies on action research, and one study about lesson studies.

Table 1 Focus of teacher professional development

\begin{tabular}{|c|c|c|c|c|c|c|c|c|c|c|}
\hline \multirow{2}{*}{ Focus of TPD } & \multicolumn{9}{|c|}{ Year 2010 (onward) } & \multirow[b]{2}{*}{ SUM } \\
\hline & 10 & 11 & 12 & 13 & 14 & 15 & 16 & 17 & 18 & \\
\hline Observation research & 1 & 1 & 4 & 1 & 2 & 1 & 2 & 1 & 1 & 14 \\
\hline Action research & & 1 & 1 & 1 & 1 & & 1 & 1 & 1 & 7 \\
\hline Lesson study & & & & 1 & & & & & & 1 \\
\hline
\end{tabular}

\section{Observation research}

From Table 1, it is clear that the research trends from 2010-2018 are dominated by observation research. These studies were found in fourteen articles and can be grouped into three classifications: the use of ICT, the exploration of formal and non-formal activities and professionalism. The first classification concerns the use of ICT in encouraging teachers to develop the teaching skills needed in the $21 \mathrm{st}$ century. The use of ICT varies from computer literacy and activities in online communities, to engaging in online courses provided by international universities and companies (Coursera.org). Son, Robb and Charismiadji (2011) examine the current level of computer literacy of English teachers and investigated factors affecting their use of computers in classrooms. They concluded that teachers use a limited number of computer applications such as word processing, so more teacher training programmes are needed to provide teachers with opportunities to learn about practical ways of using computer in their work place. Different from the previous studies, Murugaiah, Azman, Thang and Krish (2012) developed online communities among a group of teachers to help them grow professionally with the use of online tools. The participants' lacked trust and individual characteristics and their inherent personal goals, beliefs, expectations and other issues overrode their commitment to the community. Teacher interactions need to be enhanced to feature more two-way interactions making them aware of collaborative learning behaviours, namely the higher levels of learning. The usefulness of ICT for TPD was studied by Silvia (2015), who examines the extent to which a virtual course for a professional development programme run by Coursera (coursera.org) benefits English teachers participating in the programme. Although virtual courses are a new method in TPD, most participants have positive attitudes towards the nature and content of the course and feel that the course gives positive impact on their teaching philosophy and practice. Similarly, Khalid (2014) explores the factors that influence the way teachers behave in online communities. In this study, the participants have positive views of the benefits and the importance of online communities, but the teachers indicated some hindrances to being more open towards giving comments; some teachers view joining the community as an unimportant task. 
The second classification concerns the exploration of various formal and nonformal activities, and the institutional environment. Petras, Jamil and Mohamed (2012) explore various formal and non-formal activities, and the institutional environment of in-service teacher learning. Formal activities are courses organised by educational authorities. The exclusion of educators in creating formal TPD systems creates the alienation of teachers from policy making. Furthermore, the study informs that formal courses are not very effective in aiding teachers with their teaching practice. In addition, Zein (2016a) identifies suggestions to improve PD programmes held by government-based training agencies to help enhance teachers' instructional practice. The model proposed in his study argues for the need to separate the facilitative and expertise roles between those involved with TPD (educational authorities and teacher educators). Teachers not only engage in formal TPD but also informal TPD. Canh and Minh (2012) explore the influence of the school context on teachers' engagement in informal learning activities and towards the goal of improving students' communicative competence in English. They conclude that it is necessary to adopt new theories of workplace learning or community practice as sources of new ideas for TPD. The last study by Wichadee (2012) investigates English language university teachers' professional development, the factors related to their development, the activities they used and the obstacles they encountered.

Studies on the professional becoming of teachers and the TPD needed by primary and secondary school teachers as a third classification, are examined in five studies. Yuwono and Harbon (2010) explore how English teachers improve their professionalism and their continuous TPD amidst recent changes and difficulties. They conclude that one's initial motives for entering the English teaching profession brings implications to teachers' professionalism and further growth. In addition, early interest in English, personal and environmental factors contribute to teachers' professionalism (Amin, 2014). However, Zein (2016b) investigates the professional development (PD) needs of primary English teachers. Similarly, Noom-Ura (2013) surveys problems on the different teaching skills focus ten years ago and compares them with those in the present. Recently, teachers desire the improvement of teaching strategies for communication skills, while ten years ago teachers perceived that the most important foci were reading and writing skills. Thus, TPD is needed to facilitate teachers who face this problem. In addition, Noom-Ura proposes that it is worth conducting a follow-up study to determine whether the participants of TPD can solve their teaching problems. Finally, Teo (2018) explores the use of a corpus of classroom discourse data to facilitate English TPD. According to the above studies, observation research seems to benefit teachers regarding the use of ICT in their teaching and TPD. In addition, the studies highlight teaching problems due to the shift in teaching focus, and the way that teachers construct their professional development amidst recent changes and difficulties. 


\section{Action Research}

The study by Kemmis (1982, cited in Jiang, 2017) states that action research refers to reflective inquiry carried out by participants in social situations to improve their theoretical levels and practices. From seven action studies, five are concerned with the effect of TPD on different groups; two studies are concerned with the TPD model. Koh (2011) examines the effect of TPD on two different groups. The first group comprises teachers who are involved in ongoing and sustained TPD; the second group consists of teachers who are given only shortterm TPD. He concludes that TPD for in-service teachers cannot only be viewed as an ad hoc event, since sustainability factors are important in the planning and implementation of TPD. Taking different route, Soebari and Aldridge (2016) investigate the differential effectiveness of a TPD programme for rural and urban classrooms. They suggest to TPD programme organisers to take into account the context and setting of teachers' workplace, because the usefulness of knowledge and skills imparted during a TPD programme are different between teachers in urban than rural schools. However, Lim et al. (2014) examine the impact of TPD on the changes in participating teachers' beliefs and practices. They conclude that research has the possibility to improve the practices of both the individual and organisation through the participation of all major stakeholders. Different to previous studies, Mukrim (2017) uses collaborative action research during one semester to investigate its impact on teachers' pedagogical practice. He concludes that, after engaging collaborative action research (CAR), teachers shifted their teaching delivery and, as a result, the students' interest in learning English was increased. Finally, Hale, Nani and Hooper (2018) use conversation analysis action research to enhance teacher awareness and improve classroom practices. They demonstrate that conversation analysis (CA) has the power to show significant features of the talk occurring in teachers' classrooms. In recognising these features, teachers can actually change their approach to their practice.

A TPD model, described by Soebari and Aldridge (2015), was used for guiding teachers for one year. The evaluation of teachers' change incorporates students' perceptions. The researchers concluded that the students' perceptions provided a good indication of the usefulness of the TPD programme. Likewise, Sari (2012) introduces and trials online learning communities (OLCs) with teachers to explore the feasibility of this model in supporting TPD. She finds that OLCs for TPD (OLC4TPD) can be used to conduct collaborative and reflective TPD for teachers, school leaders and teacher educators. From the above studies, action research seems to provide teachers with at least three benefits. First, action research enables teachers to use the concept of collaborative work in improving pedagogical skills. Second, it motivates teachers to change how they approach their pedagogical practice and beliefs. Third, it stimulates teachers to shift their teaching delivery, which increases the students' interest in learning English.

Only one lesson study carried out by Copriady (2013) was found. The study explores teachers' perspectives on the use of the lesson study strategy to improve the quality of their teaching. Even though acceptance about the lesson study programme is still at a moderate level, this programme enables teachers to use the 
concept of collaborative work in improving pedagogical skills. The following section discusses the types of TPD that characterise its effectiveness.

\section{Types of TPD}

Table 2 includes types of professional development as a second theme, using Hunzicker's proposed checklist. It consists of five subthemes: job-embedded, collaborative, ongoing, supportive and instructional focus. The checklist is used to indicate the effectiveness of TPD.

Table 2 Types of professional development

\begin{tabular}{|c|c|c|c|c|c|c|c|c|c|c|c|}
\hline \multirow{2}{*}{ No. } & \multirow{2}{*}{ Type of TPD } & \multicolumn{9}{|c|}{ Year 2010 (onward) } & \multirow[b]{2}{*}{ Sum } \\
\hline & & 10 & 11 & 12 & 13 & 14 & 15 & 16 & 17 & 18 & \\
\hline 1. & Job-embedded & & 2 & 2 & 2 & 1 & 1 & 1 & & 1 & 10 \\
\hline 2. & Collaborative & & 1 & 2 & 1 & 1 & 1 & 1 & 1 & & 8 \\
\hline 3. & Ongoing & 1 & 2 & 1 & 1 & 1 & & 1 & 1 & & 8 \\
\hline 4. & Supportive & & 2 & 2 & & 2 & & & & & 6 \\
\hline 5. & Instructional focus & & 1 & & 2 & & & 1 & & & 4 \\
\hline
\end{tabular}

Job-embedded TPD studies, which are connected to teachers' daily responsibilities, were found in ten studies. Son et al. (2011) provides a picture about skills and competencies in the use of computers for teachers' teaching practices and professional development. The implementation of computer-assisted language learning (CALL), which includes various activities using computers, requires language teachers to build their computer knowledge and skills. Koh (2011) observed teachers who had been involved for two school years and it was evident that sustained TPD had increased significantly in the assessment of literacy. Prior to engaging in TPD, an English teacher develops children's learning so they are ready to take an exam; after participating in ongoing TPD, the teacher becomes more result-orientated. In the form of reflective and collaborative practices, professional seminars are useful for TPD in the implementation of a new student-centred curriculum (Canh \& Minh, 2012).

Comparatively, Petras et al. (2012) study non-formal TPD activities that occur as part of the daily teaching practice, such as sharing ideas and experiences on teaching, whereas Soebari and Aldridge (2015), Lim et al. (2014) and Silvia (2015) investigate the changes of teacher-participants' teaching practices after joining TPD. However, Noom-Ura (2013) surveys English-teaching problems related to successful teaching in secondary schools. In comparison to previous studies, Soebari and Aldridge (2016) argue that there are disparities between the usefulness of the knowledge and skills imparted during the TPD programme for urban and rural school teachers, whereas Teo (2018) discusses the results of utilising actual corpus resources in aiding teachers' reflective practice and their TPD. From the above studies, job-embedded TPD has the purpose to resolve teachers' daily responsibilities, such as skills and competencies in the use of computers, sharing ideas and experiences on teaching and facing a new studentcentred curriculum. 
A collaborative subtheme, which engages teachers in both active and interactive learning, is found in eight studies. Koh (2011) concludes that teachers should be encouraged to collaborate with their peers through school-based learning communities to encourage professional development; however, Sari (2012) finds that online learning communities create new possibilities for teachers, school leaders and teacher educators to conduct collaborative professional learning, which was previously difficult due to various constraints. In addition, Khalid et al. (2014) find that teachers consider online learning communities as useful means to enhance their pedagogical skills and to exchange in ideas with teachers from other schools; Silvia (2015) reveals that online TPD platforms provide teachers with a means to collaborate with each other to improve their professional development. However, Copriady (2013) remarks that lesson study greatly benefits teachers because it allows them to collaborate with their school administrators to enhance their potential and professional development. Mukrim (2017) finds that collaborative action research is beneficial to teachers in their professional development. Soebari and Aldridge (2016) suggest TPD that focuses on encouraging teachers to improve their professionalism through reflective participation. In contrast to the above findings, Canh and Minh (2012) find that most teachers are not comfortable with collaborative learning due to the evaluative culture embedded in traditional Vietnamese culture. In summary, collaborative TPD supports teachers in enhancing their pedagogical skills, and enables them to exchange ideas with teachers from other schools. Furthermore, it allows teachers to collaborate with their school administrator to enhance their teaching practice.

Eight studies contained an ongoing TPD subtheme, which is a combination of contact hours, duration, and coherence. Yuwono and Harbon (2010) explore how English teachers improve their professionalism and their continuous professional development amidst recent changes and difficulties. Similarly, Wichadee (2012) reveals factors that support or constrain university English teachers to continue their self-development, and Amin (2014) also reveals that awareness and commitment are two teachers' qualities that drive them to continue their professional development. Moreover, Koh (2011) concludes that ongoing, sustained professional development is more effective in developing teachers' professional development compared to one attempt at TPD workshops. However, Sari (2012) demonstrates a one-year online learning community (OLC4TPD) programme feasibility as an ongoing and flexible TPD model, while Soebari and Aldridge (2015) develop and implement a TPD model in five phases. They use students' perceptions to evaluate the effectiveness of TPD. Nguyen (2016) explores how four Vietnamese English language teachers of young learners continued developing their PD by joining other communities. In contrast with the previous study, Soebari and Aldridge (2016) studied a one-year MGMP Empowerment Programme conducted in a rural and an urban school. Ongoing TPD benefits teachers in improving their practice. The longer teachers engage in $\mathrm{TPD}$, the more significant the improvement in their teaching practice. 
Supportive TPD studies, which are concerned with factors that support teachers in doing their task, were found in six studies. Petras et al. (2012) concluded that educational authorities in Malaysia provided a wide range of professional development courses for teachers. The TPD system in Malaysia consists of formal training programmes, a professional support network and several types of allowances and incentives. Teachers are more motivated to continue their PD when school leaders facilitate their learning and when students are demanding (Canh \& Minh, 2012). Teachers' commitment, personality traits, resilience, environmental factors, and teaching inspectors influenced teachers' willingness to continue their TPD (Amin, 2014). Unlike previous studies, Son et al. (2011) found that despite their limited internet access and competency when using computer assisted language learning (CALL), teachers showed highly positive attitudes and felt comfortable using computers. Online communities, as a new method of peer communication, help teachers to expand their network, which include teachers from other schools to obtain new ideas and to enhance their TPD (Khalid, Joyes, Ellison \& Daud, 2014). In addition, Copriady (2013) revealed that teachers were confident with the benefits of using lesson studies to improve their TPD. To summarise, teachers are motivated to engage in TPD when the school leaders are willing to facilitate their learning and when students become demanding. Moreover, their commitment, personality traits, and resilience influence their willingness to continue their TPD.

Four TPD instructional foci emphasising on student learning outcomes involve the study and application of content and pedagogy. As teachers encounter problems in their daily work, various training is needed to help them. Koh (2011) helps teachers to design authentic classroom assessments and rubrics; Noom-Ura (2013) provides suggestion on how to resolve teachers' problems in teaching writing and speaking and listening. Zein (2016) concludes that English teachers need training on the selection and adaptation of teaching materials, while Soebari and Aldridge (2015), during phase three of their research, attempted to examine the ideas and put the teachers' translated concepts that were imparted during the TPD programme into practice. From the above studies, instructional focus TPD seems to enhance teachers' mastery on daily tasks such as creating classroom assessments, teaching writing, listening, speaking, and selecting and adopting teaching materials.

The reviewed studies have discussed the various types of effective TPD according to Hunzicker's list. Most of the studies include the job-embedded type, which connects to teachers' daily responsibilities, such as activities using computers, the implementation of a new student-centred curriculum, and sharing ideas and experiences of teaching. Online communities and online courses provide for the possibility collaborative teacher engagement or ongoing TPD, with lower costs and less time consumption in comparison to on-site workshops or seminars. 


\section{CONCLUSION}

This study was designed to explore TPD studies for English teachers in South East Asia due to the shift of focus of English learning from grammar to conversational English along with the use of computers in classrooms. Using the checklist, which included supportive, job-embedded, instructional focus, and ongoing components for the TPD analysis model, the researchers found that TPD studies are conducted within two focuses: (1) action research; and (2) observation research. The action research studies vary in terms of methods used. Comparing two groups of participants was frequently used, for example comparing rural and urban groups of teachers, and a group that was given long-term TPD compared to a group participating for only a short time. However, when the internet was initially used in education, online learning communities were used as a model of TPD. Recent studies, which employ collaborative and conversation analysis, aim to enhance teacher awareness and improve pedagogical and classroom practice. This type of TPD is in line with Zeichner (2010), who proposed the concept of 'third space', which aims to reject binaries such as practitioners and academic knowledge, or theory and practice.

TPD activities are needed due to changes in the English curriculum and the use of computers in classrooms. The aim of English learning in school has changed its focus from grammar to conversational English. English teachers have difficulties in practicing English communication skills because they do not use English as their daily communication language. The use of notebook computers in class, although a costly new piece of equipment, also cause problems with literacy problem to begin with. Although the governments conduct various TPDs to improve teacher performance, they are often not very effective in aiding teachers with their teaching practice. Some studies, in considering the ineffectiveness of formal TPD, give suggestions and models of effective formal TPD.

Job-embedded TPD is most frequently used to help teachers solve problems in their teaching problem and is connected to teachers' daily responsibilities. Studies that use ICT showed that collaborations among teachers are more feasible when using the internet in the form of online communities or online courses. This mode of activity can engage teachers in both active and interactive learning. Teachers' pedagogical practices are more likely to improve if they are engaged in TPD programmes for an extended period.

This study also discovered that teachers are often constrained by several factors, so they are unable to engage in a TPD programme. Hence, teachers need support both from their schools and outside school parties to motivate and facilitate teachers in engaging with TPD programmes. The current policy of TPD needs to consider this support and eliminate the constraints to improve the effectiveness of TPD. Thus, future studies should investigate factors that support TPD programmes. 


\section{REFERENCE}

Amin, M. (2014). What Makes Teachers of EFL Professional or Unprofessional. Jurnal Pendidikan Humaniora, 2(4), 294-303.

Amos, Y. T. \& Kukar, N. M. (2017). Teaching and Learning Simultaneously: Collaboration between Teacher Education and a University ESL Program. In C. Martin, \& D. Polly (Eds.), Handbook of Research on Teacher Education and Professional Development (pp. 48-67). Hershey, PA: IGI Global. doi:10.4018/978-1-5225-1067-3.ch003

Bowen, G. A. (2009). Document analysis as a qualitative research method. Qualitative Research Journal, 9(2), 27-40. doi:10.3316/QRJ0902027

Copriady, J. (2013). The implementation of Lesson Study programme for developing professionalism in teaching profession. Asian Social Science, 9(12 SPL ISSUE), 176-186. https://doi.org/10.5539/ass.v9n12p176

Darling-Hammond, L., Hyler, M. E., Gardner, M. (2017). Effective Teacher Professional Development. Palo Alto, CA: Learning Policy Institute.

Day, C. \& Sachs, J. (2004). Professionalism, Performativity and Empowerment: Discourses in the Politics, Policies and Purposes of Continuing Professional Development. In C. Day, \& J. Sachs (Eds.), International Handbook on the Continuing Professional Development of Teachers (pp. 3-32). Maidenhead: Open University Press.

Guskey, T. R. (2003). What Makes Professional Development Effective? Phi Delta Kappan, 84(10), 748-750. doi:10.1177/003172170308401007

Hale, C. C., Nani, A., \& Hooper, D. (2018). Conversation Analysis in Language Teacher Education: An Approach for Reflection Through Action Research. Hacettepe University Journal of Education,33,-71. https://doi.org/http://dx.doi.org/10.16986/HUJE.2018038796

Hunzicker, J., 2011. Effective professional development for teachers: a checklist. Professional Development in Education. Professional Development in Education, 37:2, 177-179. https://doi.org/10.1080/19415257.2010.523955

Jiang, Y. (2017). A Study on Professional Development of Teachers of English as a Foreign Language in Institutions of Higher Education in Western China. Berlin: Springer Berlin.

Kasemsap, K., 2017. Teacher Education and Teacher Professional Development: Current Issues and Approaches. Handbook of Research on Teacher Education and Professional Development. IGI Global, Hershey PA, ISSN: 2327-6983; eISSN: 2327-6991. pp. 112-137.

Khalid, F., Joyes, G., Ellison, L., \& Daud, M.Y. (2014). Factors Influencing Teachers' Level of Participation in Online Communities. International Education Studies, 7(13), 23-32.

Koh, K. H. (2011). Improving teachers' assessment literacy through professional development. Teaching Education, 22(3), 255-276. https://doi.org/10.1080/10476210.2011.593164

Korthagen, F. A. J., \& Kessels, J. P. A. M. (1999). Linking Theory and Practice: Changing the Pedagogy of Teacher Education. Educational Researcher, 28(4), 4-17. https://doi.org/10.3102/0013189X028004004

Le, C. Van, \& Nguyen, M. T. T. (2012). Teacher learning within the school 
context: An ecological perspective. Indonesian Journal of Applied Linguistics (IJAL), 2, 52-67.

Lim, C. P., Tondeur, J., Nastiti, H., \& Pagram, J. (2014). Educational Innovations and Pedagogical Beliefs: The Case of a Professional Development Program for Indonesian Teachers. Journal of Applied Research in Education, 18, 1-14.

Mukrim. (2017). English Teachers Doing Collaborative Action Research (CAR): A Case Study of Indonesian EFL teachers. Pertanika J. Soc. Sci. Hum, 25(December 2016), 199-216.

Murugaiah, P., Azman, H., Thang, S. M. \& Krish, P. (2010). Teacher learning via communities of practice: A Malaysian case study. International Journal of Pedagogies and Learning, 7(2), 162-174. https://doi.org/10.5172/ijpl.2012.7.2.162

Nguyen, C. D. (2016). Creating spaces for constructing practice and identity: innovations of teachers of English language to young learners in Vietnam. Research Papers in Education, 32 (1), 56-70. https://doi.org/10.1080/02671522.2015.1129644

Noom-Ura, S. (2013). English-teaching problems in Thailand and Thai teachers' professional development needs. English Language Teaching, 6(11), 139147. https://doi.org/10.5539/elt.v6n11p139

Petras, Y., Jamil, H., \& Mohamed, R. A. (2012). How do teachers learn? A study on the policy and practice of teacher professional development in Malaysia*. KEDI Journal of Educational Policy, 9(1), 51-70.

Sari, E. R. (2012). Online learning community: A case study of teacher professional development in Indonesia. Intercultural Education, 23(1), 63-72. https://doi.org/10.1080/14675986.2012.664755

Silvia, A. (2015). Coursera Online Course: A Platform for English Teachers' Meaningful and Vibrant Professional Development. TEFLIN Journal, 26(2), 228-246. https://doi.org/10.15639/teflinjournal.v26i2/228-246

Soebari, T. S., \& Aldridge, J. M. (2015). Using student perceptions of the learning environment to evaluate the effectiveness of a teacher professional development programme. Learning Environments Research, 18(2), 163178. https://doi.org/10.1007/s10984-015-9175-4

Soebari, T., \& Aldridge, J. M. (2016). Investigating the differential effectiveness of a teacher professional development programme for rural and urban classrooms in Indonesia. Teacher Development, 20(5), 701-722. https://doi.org/10.1080/13664530.2016.1185031

Son, J., Robb, T., \& Charismiadji, I. (2011). Computer literacy and competency: A survey of Indonesian teachers of English as a foreign language. Call-Ej, 12(1), 26-42.

Teo, P. (2017). Professionalising teaching: a corpus-based approach to the professional development of teachers in Singapore professional development of teachers in Singapore. Cambridge Journal of Education, 3577(August), 1-22. https://doi.org/10.1080/0305764X.2017.1324019

Wichadee, S. (2012). Factors related to professional development of English language university teachers in Thailand. Journal of Education for Teaching, 38(5), 615-627. https://doi.org/10.1080/02607476.2013.739795 
Yuwono, G., Harbon, L. (2010). English Teacher Professionalism and Professional Development: Some Common Issues in Indonesia. Asian EFL Journal, 12(2), 145-163.

Zeichner, K. (2010). Rethinking the connections between campus courses and field experiences in college- and university-based teacher education. Journal of Teacher Education, 61(1-2), 89-99. https://doi.org/10.1177/0022487109347671

Zein, M. S. (2016a). Government-based training agencies and the professional development of Indonesian teachers of English for Young Learners: perspectives from complexity theory. Journal of Education for Teaching, 42:2, 205-223, DOI: 10.1080/02607476.2016.1143145

Zein, M. S. (2016b). Professional Development in Education Professional development needs of primary EFL teachers: perspectives of teachers and teacher educators. Professional Development in Education, 43:2, 293-313, DOI: $10.1080 / 19415257.2016 .1156013$ 